himself free to watch over the destinies of the young colony, in whose future he had unbounded faith. When Europe was distracted by the Napoleonic wars he could write to Hunter, the governor of New South Wales: "I see the future prospect of empires and dominions which now cannot be disappointed. Who knows but that England may revive in New South Wales when it is sunk in Europe." To those who were entrusted with the government of the newly established colony his advice and encouragement were invaluable. Phillip, Hunter, King and Bligh, fighting manfully to give New South Wales an orderly government and thwarted by the professional soldiers who augmented their meagre pay by trafficking in rum, poured out their troubles to him; he reciprocated by doing everything in his power to smooth over their difficulties. In Bligh, that most maligned of men, he never lost confidence. Banks knew him for an expert sailorman, a wise and just governor; he could appreciate, perhaps better than Bligh's traducers; the courage which had been required of the latter when he navigated the loyal men of the Bounty through the Timor Sea. And all the time, intermingled with his words of counsel and encouragement, were requests for specimens of plants and any information which might be of value to men of science. It was not to be a one-way traffic in plants. "My business," said Banks to Hunter, is to be "the encourager of the transport of plants from one country to another." The young colony needed a supply of "useful plants"-hops, for example, were to be shipped to New South Wales in the hope that beer would diminish the consumption of rum; and it was Banks who tried to ensure that the colonists' needs were supplied. There were, of course, disappointments. Consignments of specimens were sometimes lost at sea, on homeward and outward voyages, and official support was not always forthcoming in London; but Banks never lost heart ; and he could boast to Hunter that "we shall before it is long see her [Great Britain's] ministers made sensible of its [New South Wales's] real value". It is not to be wondered that our kinsmen in Australia look upon Banks as the 'godfather' of their country, and have zealously collected a great wealth of his papers.

Banks was unquestionably a great European. In London his name was a household word; even the humblest citizen knew of the "great Sir Joseph" who lived in Soho Square. Abroad, men of science looked upon him almost as the protector of all scientific effort, especially when the Napoleonic wars interrupted the free exchange of ideas between England and the Continent. Cuvier's tribute to his brave, and successful, endeavours to raise science high above the quarrels of nations is not an unfitting conclusion to this memoir. "During the long period of two and twenty years," said Cuvier, "in which war extended its ravages to every part of the two worlds, the name of Banks was in all places a palladium to such of our countrymen as devoted themselves to useful researches. If their collections were seized, they had only to address themselves to him to ensure their restoration; if their persons were detained, the time occupied in acquainting him with the fact was the only delay which was interposed between them and liberty. When the seas were closed in upon us on all sides, his voice opened a passage to our scientific expeditions. Geography and natural history are indebted to his solicitude for the preservation of their most valuable labours :- but for him our public collections might now, and perhaps for ever, be deprived of the riches which adorn them."

Banks died at his house at Spring Grove, Isleworth, on June 19, 1820: he was buried, as he wished, with neither pomp nor ceremony, in the graveyard of Heston parish church.

\section{PRODUCTION GENETICS IN SWEDEN}

\section{By DR. C. D. DARLINGTON, F.R.S.}

$\mathrm{N}^{2}$

ATIONS often have to rely for their independence on the independence of their food supply. This principle is as well understood in Sweden as in Great Britain, and for similar reasons. Since the War of 1914-18, however, Sweden's position has been greatly improved. The annual yields of wheat and sugar-beet have been increased to the point at which the country is just self-supporting. The most important factor in this increase has been the improvement in the farmer's seed by plant breeding ; indeed, one quarter of the wheat and nearly one half of the sugar harvest may be put down to the use of improved seed.

Sweden might seem to be a particularly grateful field for the plant breeder because, like Canada and the U.S.S.R., it lies on the northward margin of cultivation; any slight change in hardiness or growth-rate or light-response which pushes the limit of growth slightly farther north therefore throws open a vast new territory to cultivation. On the other hand, as we shall see, the severity of the Swedish climate does not allow the plant breeder to win his victories without a struggle. What these victories amount to I have recently had the privilege of seeing.

The foundation of Swedish success in plant breeding lies in the small village of Svalöv in Skåne, the richest and southernmost province- of Sweden. At this centre we find three partners working together. The youngest of the three is the Institute of Genetics of the University of Lund, some twenty miles from Svalöv. This is a department for teaching and research. It was established for Prof. Nilsson Ehle in 1927 and is now directed by Prof. Müntzing. The second partner is the Svalöv Plant Breeding Institute, formerly directed by Nilsson Ehle and now by Prof. Akerman. This Institute is immediately responsible for the production of new varieties, but is, at the same time, concerned with long-term research and houses a part of the Institute of Genetics. The third partner is the Swedish Seed Company, which has the monopoly of maintaining the stocks and selling the seed of the Svalöv varieties and controls each step between selection and marketing. Without this monopoly it was realized that the maintenance of scientific standards could not be guaranteed. The triple organization, now occupying about three thousand acres, arose at first from a farmers' union, but it is now supported and partly controlled by the Government.

This system has developed during the last fifty years and has grown as the field of possible activity has extended and the numbers of crops that have seemed worth while improving have increased. It began with cereal breeding and with the union, on one hand, of the new genetic analysis of quantitative inheritance in terms of cumulative factors by Nilsson Ehle and, on the other hand, of the practical under- 
standing of the plant breeding problem by the first director, Hjalmar Nilsson. This union we now see bearing fruit equally in the practical and the theoretical field.

The first development of the Svalöv organization was the formation of subsidiary stations to meet the local needs of the main climatic regions of Sweden. For example, the Undrom station deals mainly with herbage plants but also with potatoes, while in the far north (latitude $66^{\circ}$ ) the Lulea Station produces new types of barley and oats. The station at Ultuna, near Uppsala, is of the first importance, and Ultuna has recently been made the site of a centralized agricultural college for the whole of Sweden, a choice which arises not from its central geographical position but from its marginal agricultural position. The new problems and the most difficult ones are on this northern margin. Here under Prof. Turesson some of the most important work is concerned with genetic acclimatization.

The second development has been the formation of specialized stations for particular crops. For example, at the beginning of the War the shortage of textiles brought home to the authorities the importance of fibres, and the flax research was transferred to a new.laboratory under Dr. Granhall at Månsabo, near Svalöv. Just as the wheat-breeding department has its complete milling and baking installation, and the sugar-beet laboratory its complete extraction and assaying equipment, so for flax a complete retting installation has been set up, together with special apparatus for retting small selection samples. The industrial equipment necessary as a foundation for plant breeding is never spared.

Sweden's abundance of forests could not long be overlooked where the possibilities of plant breeding were considered. In 1936 a new research station was established by a Society for Breeding Forest Trees. It lies in fifty acres of experimental ground at Ekebo, near Svalöv. An expedition led by Prof. Turesson in 1938 provided a valuable collection of forest-tree seed from North America as a foundation for the work of acclimatization and hybridization.

Under Dr. Nils Sylvén, this work has already gone far. Four regional branch stations have been set up. A genetic survey of Swedish forest trees has revealed a prodigious range of variation in usefulness (just as one sees in Great Britain) both within communities and between them. The ecotype principle is singularly well demonstrated in the differences within species in regard to long- and short-day habit, for when transplanted to a different latitude the unadapted individual is obviously and entirely useless.

A special form of selection has resulted from the discovery of triploid aspens with as much as twice the growth-rates of the neighbouring diploid trees. Many of the later examples have been discovered by farmers and foresters who had been told to look out for them. These valuable trees are being propagated for their own localities, and tetraploids have also been obtained from them. The discovery of these forms has led to the systematic use of colchicine, which has been successful in producing tetraploids in Sequoia, Larix, Pinus and Abies. Artificial lighting, refrigeration and special grafting methods are being used to shorten the work of breeding and propagating.

Naturally, fruit being something of a luxury in Sweden, fruit breeding has been the last problem to be tackled, but two factors have lately directed attention to its importance. First, the damage done to the orchards in Sweden-only less serious than in Finland-by the three severest winters ever recorded, shows the necessity of producing native fruits selected for the Swedish climate. Secondly, the value of vitamin $\mathrm{C}$ in a country cut off from southern fruits is obvious. Valuable work has indeed been done in surveying the native rose population for its ascorbic acid content, and maintenance of vitamin content is regarded as an important object of potato breeding.

The origin of the fruit work at Svalöv is typical of the confident purpose of Swedish plant breeding. Triploid apples are in general not only larger but also later keeping and richer in vitamin content than diploids. In order to produce them regularly it was necessary to have tetraploids. Half a million natural seeds of the best triploid varieties were sown. All of them, of course, would be crosses with cultivated diploids. From them twenty-eight tetraploid seedlings-recognized by their larger stipules-have been obtained in the last five years. With this initial endowment the new fruit-breeding stations which are being set up at Alnarp and Balsgård will have a promising foundation.

Instead of relying on such chance origins, however, the plant breeder can now produce polyploids at will by the use of twin seedlings, collected by the seedtesting stations, by heat, and especially by colchicine treatment. These methods have been taken up with enthusiasm and success in Sweden. Tetraploid forms of clovers, lucerne, herbage grasses, barley, rye, flax, potatoes, sugar-beet and other crops have been produced and are being tested; some have already been proved of practical use. Octoploid wheat-rye hybrids, first raised in the U.S.S.R., are now regularly produced by the doubling of crosses between suitable parents for different conditions and purposes. The selection of their derivatives has made available a large range of forms of good baking quality and high yield and hardiness. In fact, a new grain crop of special value for Sweden and other countries has been created, the first such invention for three thousand years.

Research in Prof. Müntzing's department has indicated the mode of action of colchicine in arresting cell-division and doubling the chromosomes. It has also shown the nature of the anomalous systems of reproduction in herbage grasses, particularly Poa, where either meiosis, or fertilization, or both, may be omitted, with the production of new forms; where secondary polyploids breed true; and where pseudogamy depends on the fertilization of the endosperm nucleus alone. Dr. Å. Gustafsson at Svalöv has succeeded in unravelling another anomalous situation in the Canina roses by crosses which have produced new types of reproduction. These investigations are revealing principles of permanent importance in plant breeding. Similarly, the study of the nucleic acid cycles of crop plants which is now being linked up with Caspersson's cell physiology in Stockholm will lay the foundation of new methods of plant breeding.

Geneticists have long had misgivings about the value of X-ray mutations in plant breeding. Gustafsson, however, has made extensive trials and selections of the progeny of X-rayed barley in the third and fourth generations. From the variety Golden Barley he has obtained selections with as much as 10 per cent increase of yield. Whether or not these forms are directly utilizable it is clear that they provide the material of future improvements by recombination. Theuse of the X-raymethod is thereforebeing extended.

Animal breeding is generally slower than plant 
breeding and its advantages take longer to prove. Moreover, in Sweden, as in Great Britain, superstition is deeply embedded in the minds of the breeders, although it is not, as here, incorporated in official handbooks. The Swedish Animal Breeding Institute with its well-equipped laboratories is situated on an extensive stock farm at Wiad, near Stockholm. Here Prof. Bonnier has set about reducing the difficulties of the problem by applying the latest technical devices. Artificial insemination is used to make rapid progeny tests of young bulls so that the same bulls, and not their progeny, can be bred for stock improvement. Special tests, again with artificial insemination, have been made for the choice of parents in hybridvigour crosses of poultry. New breeding systems have been established for preserving standardized and uniformly cross-bred stocks of poultry by using mixed sperm. These methods are influenced by the hybridvigour technique applied with pre-eminent success by Rasmusson to sugar-beet, and to maize in the United States. Finally, the possibilities of physiological experiment with monozygous twins have been exploited by a national collection of such twins in cattle. This deserves special consideration.

One half per cent of all cattle births are twin heifers. To determine which of these are monozygous a preliminary questionnaire is put to the farmer. Those passing this test are bought and submitted to Kronacher's nose-print and hair-whorl tests. Of the first 215 applications seven pairs fulfilled the conditions of identity. In this way nearly a hundred pairs of monozygous twins have now been collected at Wiad from all over Sweden. With these it has been possible to set up physiological experiments covering the practical problems of nutrition and maintenance. From these experiments the genetical variable has been removed. Already questions have been answered with a certainty which could not otherwise have been attained at fifty times the cost. Further, the answers are of importance far beyond the field of husbandry, especially, of course, in medicine.

The lessons of practical breeding-or production genetics as we may call it-in Sweden have their lessons for Great Britain with its vast responsibilities for farm, forest and fruit crop production at home and overseas. The results depend on a policy consisting of the following coherent elements :

(1) Genetics is taught in the universities;

(2) Posts are available in genetic research for the ablest university students ;

(3) Men are therefore available to teach in the universities who have done research in this subject and thus actually understand how it works.

This is a train of events which a little thought shows is indeed necessary for the healthy development of any science. But this is only one side. The university departments carry on their work in close collaboration with the applied departments of agriculture and medicine and with the research stations. This leads to an integration of subjects and methods. It leads to a realization of the use of statistical, chemical and cytological techniques in genetics, and of genetical techniques in physiology. Finally, the research stations benefit by a direct flow of ideas and of trained personnel from the universities, and them. selves in consequence conduct long-term or 'pure' research of value.

This integration is responsible for what may be described as the engineering method of Swedish plant and animal breeding : a bold combination of scientific basis and long-term planning, with a practical pur- pose and with practical collaboration. The practical collaboration depends again on the Swedish farmer or medical man himself understanding, as a result of education and propaganda, what profit can be gained by using the latest scientific methods. Such a system and such results do not arise by individual effort or accidental whim. They depend upon an instructed national policy.

\section{ADVANCES OF CHEMICAL KINETICS IN THE SOVIET UNION}

\section{BY NIKOLAI SEMENOV}

\author{
Member of the Academy of Sciences of the U.S.S.R.
}

[The school of N. Semenov is well known to physical chemists throughout the world. Its outstanding contribution has been the application of the theory of branching reaction chains to problems of combustion and explosion. - In 1935 Semenov himself published a standard treatise on "Chemical Kinetics and Chain Reactions". His ideas have provided a comparatively easy way through many complex and mysterious phenomena. The following article describes how the theoretical and practical work of his school has developed.-Editors, NATURE.]

T $P$ to the twenties of the present century, "chemical kinetics', or the science of the regularities underlying the course of chemical transformations, was largely in obscurity. But from this time onwards it becomes one of the predominating trends of physico-chemical studies.

As regards homogeneous chemical processes, the concepts of van't Hoff and Arrhenius were to undergo considerable modification. The idea was advanced that the reactions proceed through a number of stages, or intermediate products such as free atoms and radicals or particles excited by electrons. The work of Bodenstein, Haber, Christiansen, Polanyi, Lind, Bäckström and others during 1913-28, especially experiments on the formation of hydrogen chloride and bromide, was the first to suggest the new ideas and the methods of computing the velocities of these reactions. It is in connexion with these studies that the first idea of chain reactions was inaugurated.

It will, however, be noted that no general significance was attached to chain reactions up to 1927. They were considered as confined to very few individual cases.

The situation changed appreciably in 1927, after the publication of the first papers from the Institute of Chemical Physics of the U.S.S.R., and, soon after, of quite independent studies by Hinshelwood and his school in England. It was shown that chain reactions represent a large group of chemical transformations. A theory of chain reactions was developed, new and stimulating ideas were introduced regarding branching of chains and their being cut off on the walls of the vessel : the principal laws of these reactions were deduced and verified experimentally.

From 1928 onwards, these new studies in the domain of chain reactions were discussed at physicochemical congresses and conferences throughout the world, and they have given rise to numerous experimental studies. During 1934-35, Semenov's monograph "Chain Reactions" was published in Russian and in English. This book reviews all the evidence 